\title{
Kiwifruit SVP2, a dormancy regulator
}

\author{
Rongmei Wu \\ The New Zealand Institute for Plant \& Food Research Ltd., Mt. Albert, Auckland, New Zealand
}

\section{Summary}

Kiwifruit (Actinidia spp.) are woody perennial vines where bud dormancy and outgrowth affect flower development. MADS-box genes similar to Arabidopsis SHORT VEGETATIVE PHASE (SVP) have been implicated in the regulation of flowering in annual species and in bud dormancy in perennial species. Four kiwifruit SVP-like genes have been identified. Their roles in dormancy and flowering have been analysed in Arabidopsis, tobacco and a high-chill and a low-chill kiwifruit species, Actinidia chinensis var. deliciosa and $A$. eriantha. Our detailed study of kiwifruit SVP2 that elevated expression of SVP2 suppressed bud outgrowth in the high-chill kiwifruit $A$. chinensis var. deliciosa. Sufficient winter chilling and the dormancy-breaking agent hydrogen cyanamide (Hi-Cane ${ }^{\circledR}$ ) could overcome the SVP2 effect. Transcriptomic analyses of kiwifruit SVP2 transgenic lines suggested that SVP2 mimics the well-documented effect of abscisic acid $(A B A)$ in plant dehydration response.

Keywords

kiwifruit dormancy, SVP, DAM, ABA, dehydration pathways

\section{Introduction}

Flowering in temperate woody perennials is associated with bud dormancy, when growth is repressed to ensure survival during unfavourable winter conditions. Bud dormancy is a period of temporary suspension of growth activity in response to environmental conditions, such as seasonality or extreme heat, drought, or cold. Endodormancy is the deepest state of dormancy, where inhibition of growth originates within the bud meristem and a certain amount of chilling is required before growth can resume. This is so in kiwifruit (Actinidia spp.), where the lack of sufficient chilling results in delayed budbreak, subsequently reduces flowering and impacts on fruit yield (McPherson et al., 2001; Sibley et al., 2005; Walton et al., 2009).

The molecular mechanisms that regulate dormancy in woody perennials are largely unknown. MADS box genes with similarity to Arabidopsis SVP have, however, been implicated in regulation of flowering time in annuals, and in bud dormancy in perennial species. In kiwifruit, four SVP-like genes have been identified and characterised in Arabidopsis (Wu et al., 2012). SVP2 and SVP3 are closely related, but with dissimilar seasonal expression profiles. Overexpression of SVP2 and SVP3 exhibited different competencies on preventing winter bud outgrowth (Wu et al., 2014, 2017b). This review will briefly describe the conserved and divergent roles of SVP-like genes in annual and woody perennials, in particular when associated with dormancy in Actinidia spp.

\section{Significance of this study}

What is already known on this subject?

- SVP-like genes have demonstrated roles in regulation of flowering time in annuals and suggested roles in regulation of dormancy in perennials.

What are the new findings?

- This review describes a conservation in mechanism of action between SVP genes of taxonomically distant Arabidopsis and a woody perennial kiwifruit; highlights the role of kiwifruit SVP in suppression of meristem activity to prevent precocious budbreak before the fulfilment of winter chilling requirement; presents a mode of action of SVP2 associated with dormancy release in kiwifruit.

What is the expected impact on horticulture?

- Such knowledge can help to develop new kiwifruit varieties through conventional breeding or through genetic engineering, targeting budbreak and flowering dates which ensure optimal growth and adequate production in different growing regions and environments.

\section{SVP in Arabidopsis}

In Arabidopsis, two MADS-box genes, SVP and AGAMOUS-like 24 (AGL24), are closely related, but have opposite effects in the control of flowering time (Gregis et al., 2006). SVP is expressed in vegetative seedlings, and is barely detectable in the main inflorescence apical meristem (Hartmann et al., 2000). SVP represses the floral transition. The svp mutants cause early flowering (Hartmann et al., 2000), whereas ectopic expression of SVP results in late flowering, and causes floral reversion (Brill and Watson, 2004; Masiero et al., 2004). AGL24 is expressed during vegetative and floral development (Yu et al., 2002). AGL24 promotes the floral transition. The agl24 mutants cause late flowering, whereas overexpression of AGL24 accelerates flowering (Michaels et al., 2003; Yu et al., 2004).

SVP and AGL24 are essential to prevent premature differentiation of floral meristems and to determine the appropriate timing of floral organ development (Gregis et al., 2013; Yu et al., 2004; Liu et al., 2009). Genetic interaction models have shown that the SVP protein directly binds to the promoters of the key flowering genes SOC1, FLOWERING LOCUS T (FT) and its paralogue TWIN SISTER OF FT (TSF) to repress flowering (Lee et al., 2007; Jang et al., 2009), while AGL24 promotes SOC1 expression during floral transition (Michaels et al., 2003; Liu et al., 2008). SVP and AGL24 are also capable of interacting with other proteins in response to developmental and environmental cues during floral transition (Lee et al., 2007; Li et al., 2008; Fujiwara et al., 2008; Jang et al., 2009; 
Gregis et al., 2013; Lee et al., 2014; Andrés et al., 2014). Presence and absence of SVP in the shoot apical meristem modulates gibberellin biosynthesis, and subsequently integrates gene expression in response to inductive photoperiods (Andrés et al., 2014). The interaction between AGL24 and SOC1 mediated the effect of gibberellins on flowering under shortday conditions (Liu et al., 2008). A floral repressor complex comprising SVP and FLOWERING LOCUS C (FLC) strongly delays or prevents flowering in response to vernalisation under non-inductive environments (Li et al., 2008; Mateos et al., 2015). Furthermore, SVP has been identified as a key hub gene in a transcriptional network during drought stress, linking changes in primary metabolism and the initiation of stress responses (Bechtold et al., 2016).

\section{SVP genes in perennial plants}

$S V P$-like genes in woody perennials have been proposed in regulation of growth cessation and bud dormancy during winter. SVP-like DORMANCY ASSOCIATED MADS-box (DAM) genes were first implicated as having a role in dormancy in a mutant peach (Prunus persica) named evergrowing (evg) (Wang et al., 2002). The mutant peach trees fail to set terminal buds in autumn under the dormancy-inducing shortday conditions and have a reduced chilling requirement in lateral buds to break dormancy. This mutation is caused by a deletion of six tandemly repeated DAM (DAM1-6) genes at the peach EVERGROWING locus (EVG) (Bielenberg et al., 2008). Expression of peach DAM1, 2, 4 is correlated with growth cessation and bud set. DAM3 does not show a distinct expression pattern throughout the annual cycle, while DAM5 and DAM6 are upregulated by SD conditions and downregulated by low temperature (Li et al., 2009). Highly similar $D A M$ genes are also upregulated expression and proposed association with regulation of endodormancy in other Rosaceae species: Malus spp., Rubus idaeus, Prunus spp., and Pyrus pyrifolia (Mazzitelli et al., 2007; Yamane et al., 2008; Ubi et al., 2010; Leida et al., 2012; Liu et al., 2012; Takemura et al., 2013; Mimida et al., 2015; Niu et al., 2016; Wu et al., 2017a). Ectopic expression of the Prunus mume DAM gene in transgenic poplar and apple DAMb and SVPa in apple 'Royal Gala' delayed budbreak, implicating $S V P$-like genes in the regulation of dormancy (Sasaki et al., 2011; Wu et al., 2017a). SVPlike genes from plants outside the Rosaceae-specific DAM subclade, such as grape, leafy spurge, citrus, and sapphire dragon tree eucalyptus, have also been suggested to be involved in regulation of dormancy (Prakash and Kumar, 2002; Brill and Watson, 2004; Diaz-Riquelme et al., 2009; Li et al., 2010; Horvath et al., 2010; Liu et al., 2012; Sun et al., 2016). However, most of these proposals were based simply on observing elevated expression during endodormancy: evidence of causality is lacking.

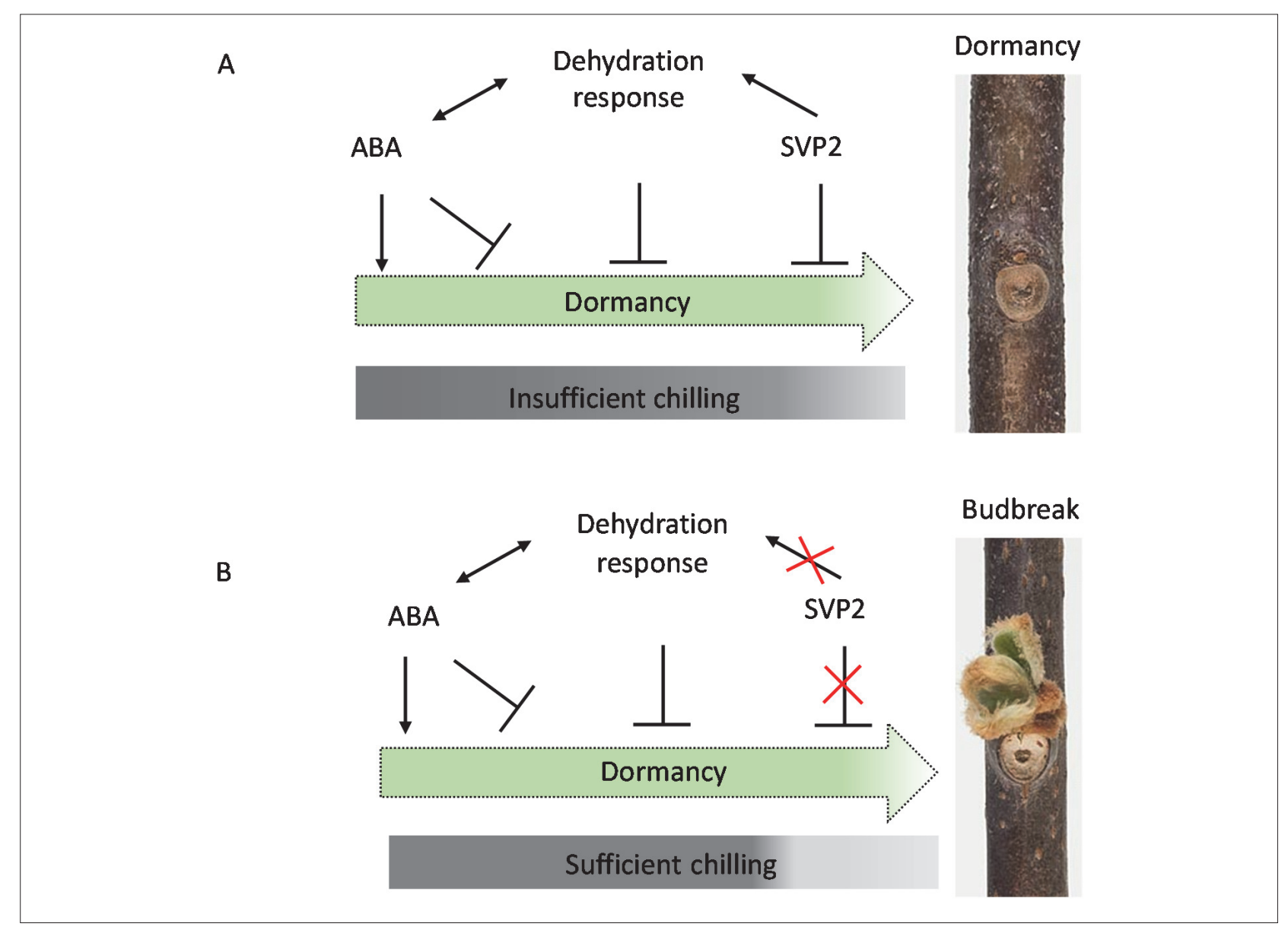

FIGURE 1. The mode of action of SVP2 in regulation of dormancy in kiwifruit. A. Insufficient winter chilling resulted in delayed budbreak. Abscisic acid (ABA) and dehydration responsive genes promote bud dormancy and repress dormancy release. When the chilling requirement is not satisfactorily met, SVP modulates expression of dehydration responsive genes to maintain bud at dormant states. B. Sufficient winter chilling promotes budbreak. Once chilling requirement is met, SVP effects are removed, which allows budbreak. Lines with arrows represent activation, while lines with bar heads represent repression. The red crosses denote inactivation. 


\section{SVP genes in kiwifruit (Actinidia spp.)}

Kiwifruit and kiwiberry (Actinidia spp.) are economically important fruit crops. All Actinidia species are deciduous perennial plants with a vigorous climbing or straggling growth habit (Ferguson, 2013). The process of flower development is spread over two growing seasons (Walton et al., 1997, 2001). Four SVP-like genes have been identified and characterized (Wu et al., 2012). The seasonal expression analyses revealed increased transcript levels of three of SVP-like genes (SVP1, 2 and 4) over the winter dormancy period, while SVP3 was not coordinated with seasonal change. Overexpression of SVP3 in kiwifruit $A$. chinensis var. deliciosa and A. eriantha did not delay budbreak in the spring, but affected floral development and anthocyanin biosynthesis pathways (Wu et al., 2014). SVP2 (which is closely related to SVP3) was expressed in all vegetative tissues, predominantly in the buds. Seasonal expression analysis showed that SVP2 expression was elevated over the winter and declined prior to budbreak. The expression of SVP2 declined more rapidly on the vines treated with dormancy-breaking agent, hydrogen cyanamide (Hi-Cane ${ }^{\circledR}$ ) treated vines than non-treated vines (Wu et al., 2012). SVP2 exhibited a growth inhibition role in transgenic tobacco on seed germination, root formation and plant height (Wu et al., 2017b). Ectopic expression of SVP2 in kiwifruit had a detrimental effect on regeneration and growth during the tissue culture stage. The most striking phenotypic effect of SVP2 was delayed budbreak in spring in the high-chill kiwifruit species, A. chinensis var. deliciosa. In contrast, SVP2 overexpression had a minimal effect on dormancy in the low-chill species, $A$. eriantha. Furthermore, sufficient winter chilling could overcome the SVP2 effect on dormancy. Transcriptomic analysis of SVP2 in A. chinensis var. deliciosa transgenic lines identified that most SVP2 downstream targets were associated with $\mathrm{ABA}$ and dehydration response pathways (Wu et al., 2017b). Genome-wide identification of direct targets of SVP2 in kiwifruit A. chinensis using chromatin immunoprecipitation followed by high-throughput sequencing (ChIP-seq) technology confirmed target genes in ABA- and dehydration-mediated growth repression. Kiwifruit SVP2 target genes also are largely overlapping with Arabidopsis SVP targets (Wu et al., 2017c).

To summarise what is currently known about kiwifruit SVP2, a proposed mode of action of SVP2 in regulation of dormancy in the high-chill kiwifruit species is shown in Figure 1. ABA enhances the dormancy establishment and suppresses dormancy release, which also regulates genes associated with dehydration pathways. SVP2 also regulates genes in the dehydration pathway. With insufficient winter chilling, SVP2, combined with dehydration pathway genes, acts to repress bud dormancy release. When chilling requirement is fulfilled, SVP2 effects are removed, resulting in budbreak.

\section{Perspective}

The work reviewed here has demonstrated the role of SVP2 in preventing precocious budbreak by suppressing meristem activity during winter dormancy (Wu et al., 2017b). Kiwifruit SVP2 also played a growth inhibition role during plant development. It is highly likely that SVP2 protein associate with other proteins to regulate gene expression. Indeed, SVP2 may have multiple downstream targets that assist in dormancy maintenance and release. Future work should focus on identifying the genes regulated by SVP2 and the proteins that interact with and modify the function of SVP2: this will elucidate the genes, pathways and biochemical aspects underlying the growth inhibitory role of SVP2.

\section{Acknowledgments}

This work was funded by the New Zealand Ministry of Business, Innovation and Employment grants C10X0816 and C11X1602. Author thanks Prof. R. Macknight and Dr. E. Varkonyi-Gasic for critical reading and comments on the manuscript.

\section{References}

Andrés, F., Porri, A., Torti, S., Mateos, J., Romera-Branchat, M., GarciaMarinez, J.L., Fornara, F., Gregis, V., Kater, M.M., and Coupland, G. (2014). SHORT VEGETATIVE PHASE reduces gibberellin biosynthesis at the Arabidopsis shoot apex to regulate the floral transition. Proc. Natl. Acad. Sci. 111, e2760-2769. https://doi.org/10.1073/ pnas.1409567111.

Bechtold, U., Penfold, C.A., Jenkins, D.J., Legaie, R., Moore, J.D., Lawson, T., Matthews, J.S., Vialet-Charbrand, S.R.M., Baxter, L., and Subramaniam, S. (2016). Time-series transcriptomics reveals that AGAMOUS-LIKE22 affects primary metabolism and developmental processes in drought-stressed Arabidopsis. Plant Cell 28, 345-366. https://doi.org/10.1105/tpc.15.00910.

Bielenberg, D.G., Wang, Y., Li, Z.G., Zhebentyayeva, T., Fan, S.H., Reighard, G.L., Scorza, R., and Abbott, A.G. (2008). Sequencing and annotation of the evergrowing locus in peach [Prunus persica (L.) Batsch] reveals a cluster of six MADS-box transcription factors as candidate genes for regulation of terminal bud formation. Tree Genet. and Genomes 4, 495-507. https://doi.org/10.1007/s11295007-0126-9.

Brill, E.M., and Watson, J.M. (2004). Ectopic expression of a Eucalyptus grandis SVP orthologue alters the flowering time of Arabidopsis thaliana. Funct. Plant Biol. 31, 217-224. https://doi.org/10.1071/ FP03180.

Diaz-Riquelme, J., Lijavetzky, D., Martinez-Zapater, J.M., and Carmona, M.J. (2009). Genome-wide analysis of MIKCC-Type MADS box genes in grapevine. Plant Physiol. 149, 354-369. https://doi.org/10.1104/ pp.108.131052.

Ferguson, A.R. (2013). Kiwifruit: the wild and the cultivated plants. Adv. Food Nutr. Res. 68, 15-32. https://doi.org/10.1016/B978-0-12394294-4.00002-X.

Fujiwara, S., Oda, A., Yoshida, R., Miyata, K., Tomozoe, Y., Tajima, T., Nakagawa, M., Hayashi, K., Coupland, G., and Mizoguchi, T. (2008). Circadian clock proteins LHY and CCA1 regulate SVP protein accumulation to control flowering in Arabidopsis. Plant Cell 20, 2960-2971. https://doi.org/10.1105/tpc.108.061531.

Gregis, V., Sessa, A., Colombo, L., and Kater, M.M. (2006). AGL24, SHORT VEGETATIVE PHASE, and APETALA1 redundantly control AGAMOUS during early stages of flower development in Arabidopsis. Plant Cell 18, 1373-1382. https://doi.org/10.1105/tpc.106.041798.

Gregis, V., Andrés, F., Sessa, A., Guerra, R.F., Simonini, S., Mateos, J.L., Torti, S., Zambelli, F., Prazzoli, G.M., Bjerkan, K.N., Grini, E.P., Pavsi, G., Colombo, L., Coupland, G., and Kater, M.M. (2013). Identification of pathways directly regulated by SHORT VEGETATIVE PHASE during vegetative and reproductive development in Arabidopsis. Genome Biol. 14, R56. https://doi.org/10.1186/gb-2013-14-6-r56.

Hartmann, U., Hohmann, S., Nettesheim, K., Wisman, E., Saedler, H., and Huijser, P. (2000). Molecular cloning of SVP: a negative regulator of the floral transition in Arabidopsis. Plant J. 21, 351-360. https:// doi.org/10.1046/j.1365-313x.2000.00682.x.

Horvath, D.P., Sung, S., Kim, D., Chao, W., and Anderson, J. (2010). Characterization, expression and function of DORMANCY ASSOCIATED MADS-BOX genes from leafy spurge. Plant Mol. Biol. 73, 169-179. https://doi.org/10.1007/s11103-009-9596-5. 
Jang, S., Torti, S., and Coupland, G. (2009). Genetic and spatial interactions between FT, TSF and SVP during the early stages of floral induction in Arabidopsis. Plant J. 60, 614-625. https://doi. org/10.1111/j.1365-313X.2009.03986.x.

Lee, J.H., Chung, K.S., Kim, S.K., and Ahn, J.H. (2014). Post-translational regulation of SHORT VEGETATIVE PHASE as a major mechanism for thermoregulation of flowering. Plant Signal. and Behav. 9, e28193. https://doi.org/10.4161/psb.28193.

Lee, J.H., Yoo, S.J., Park, S.H., Hwang, I., Lee, J.S., and Ahn, J.H. (2007). Role of SVP in the control of flowering time by ambient temperature in Arabidopsis. Genes Dev. 21, 397-402. https://doi.org/10.1101/ gad.1518407.

Leida, C., Conejero, A., Arbona, V., Gómez-Cadenas, A., Llácer, G., Badenes, M.L., and Ríos, G. (2012). Chilling-dependent release of seed and bud dormancy in peach associates to common changes in gene expression. PloS one 7, e35777. https://doi.org/10.1371/ journal.pone.0035777.

Li, D., Liu, C., Shen, L., Wu, Y., Chen, H., Robertson, M., Helliwell, C.A., Ito, T., Meyerowitz, E., and Yu, H. (2008). A repressor complex governs the integration of flowering signals in Arabidopsis. Dev. Cell 15, 110-120. https://doi.org/10.1016/j.devcel.2008.05.002.

Li, Z.G., Reighard, G.L., Abbott, A.G., and Bielenberg, D.G. (2009). Dormancy-associated MADS genes from the EVG locus of peach [Prunus persica (L.) Batsch] have distinct seasonal and photoperiodic expression patterns. J. Exp. Bot. 60, 3521-3530. https://doi. org/10.1093/jxb/erp195.

Li, Z.M., Zhang, J.Z., Mei, L., Deng, X.X., Hu, C.G., and Yao, J.L. (2010). PtSVP, an SVP homolog from trifoliate orange (Poncirus trifoliata L. Raf.), shows seasonal periodicity of meristem determination and affects flower development in transgenic Arabidopsis and tobacco plants. Plant Mol. Biol. 74, 129-142. https://doi.org/10.1007/ s11103-010-9660-1.

Liu, C., Chen, H., Er, H.L., Soo, H.M., Kumar, P.P., Han, J.H., Liou, Y.C., and Yu, H. (2008). Direct interaction of AGL24 and SOC1 integrates flowering signals in Arabidopsis. Development 135, 1481-1491. https://doi.org/10.1242/dev.020255.

Liu, C., Xi, W.Y., Shen, L.S., Tan, C.P., and Yu, H. (2009). Regulation of floral patterning by flowering time genes. Dev. Cell 16, 711-722. https://doi.org/10.1016/j.devcel.2009.03.011.

Liu, G., Li, W., Zheng, P., Xu, T., Chen, L., Liu, D., Hussain, S., and Teng, Y. (2012). Transcriptomic analysis of 'Suli' pear (Pyrus pyrifolia white pear group) buds during the dormancy by RNA-Seq. BMC Genomics 13, 700. https://doi.org/10.1186/1471-2164-13-700.

Mateos, J.L., Madrigal, P., Tsuda, K., Rawat, V., Richter, R., RomeraBranchat, M., Fornara, F., Schneeberger, K., Krajewski, P., and Coupland, G. (2015). Combinatorial activities of SHORT VEGETATIVE PHASE and FLOWERING LOCUS $\mathrm{C}$ define distinct modes of flowering regulation in Arabidopsis. Genom. Biol. 16, 31. https://doi. org/10.1186/s13059-015-0597-1.

Mazzitelli, L., Hancock, R.D., Haupt, S., Walker, P.G., Pont, S.D.A., McNicol, J., Cardle, L., Morris, J., Viola, R., Brennan, R., Hedley, P.E., and Taylor, M.A. (2007). Co-ordinated gene expression during phases of dormancy release in raspberry (Rubus idaeus L.) buds. J. Exp. Bot. 58, 1035-1045. https://doi.org/10.1093/jxb/erl266.

McPherson, H., Richardson, A., Snelgar, W., and Currie, M. (2001). Effects of hydrogen cyanamide on budbreak and flowering in kiwifruit (Actinidia deliciosa 'Hayward'). N. Z. J. Crop Hortic. Sci. 29, 277-285. https://doi.org/10.1080/01140671.2001.9514189.

Michaels, S.D., Ditta, G., Gustafson-Brown, C., Pelaz, S., Yanofsky, M., and Amasino, R.M. (2003). AGL24 acts as a promoter of flowering in Arabidopsis and is positively regulated by vernalization. Plant J. 33, 867-874. https://doi.org/10.1046/j.1365-313X.2003.01671.x.
Mimida, N., Saito, T., Moriguchi, T., Suzuki, A., Komori, S., and Wada, M. (2015). Expression of DORMANCY-ASSOCIATED MADS-BOX (DAM)-like genes in apple. Biol. Plantarum 59, 237-244. https://doi. org/10.1007/s10535-015-0503-4.

Niu, Q., Li, J., Cai, D., Qian, M., Jia, H., Bai, S., Hussain, S., Liu, G., Teng, Y., and Zheng, X. (2016). Dormancy-associated MADS-box genes and microRNAs jointly control dormancy transition in pear (Pyrus pyrifolia white pear group) flower bud. J. Exp. Bot. 67, 239-257. https://doi.org/10.1093/jxb/erv454.

Prakash, A.P., and Kumar, P.P. (2002). PkMADS1 is a novel MADS box gene regulating adventitious shoot induction and vegetative shoot development in Paulownia kawakamii. Plant J. 29, 141-151. https:// doi.org/10.1046/j.0960-7412.2001.01206.x.

Sasaki, R., Yamane, H., Ooka, T., Jotatsu, H., Kitamura, Y., Akagi, T., and Tao, R. (2011). Functional and expressional analyses of PmDAM genes associated with endodormancy in Japanese apricot (Prunus mume). Plant Physiol. 157, 485-497. https://doi.org/10.1104/ pp.111.181982.

Sibley, J.L., Dozier Jr., W.A., Pitts, J.A., Caylor, A.W., Himelrick, D.G., and Ebel, R.C. (2005). Kiwifruit cultivars differ in response to winter chilling. Small Fruits Rev. 4, 19-29. https://doi.org/10.1300/ J301v04n04_04.

Sun, L.-M., Zhang, J.-Z., and Hu, C.-G. (2016). Characterization and expression analysis of PtAGL24, a SHORT VEGETATIVE PHASE/ AGAMOUS-LIKE 24 (SVP/AGL24)-type MADS-Box gene from Trifoliate orange (Poncirus trifoliata L. Raf.). Frontiers in Plant Science 7, 823. https://doi.org/10.3389/fpls.2016.00823.

Takemura, Y., Kuroki, K., Matsumoto, K., Ban, Y., Moriguchi, T., and Tamura, F. (2013). Identification and expression analysis of candidate genes related to endodormancy induction and breaking in Pyrus pyrifolia. Sci. Hortic. 155, 65-71. https://doi.org/10.1016/j. scienta.2013.02.018.

Ubi, B.E., Sakamoto, D., Ban, Y., Shimada, Y., Ito, A., Nakajima, I., Takemura, Y., Tamura, F., Saito, T., and Moriguchi, T. (2010). Molecular cloning of dormancy-associated MADS-box gene homologs and their characterization during seasonal endodormancy transitional phases of Japanese pear. J. Am. Soc. Hortic. Sci. 135, 174-182.

Walton, E.F., Fowke, P.J., Weis, K., and McLeay, P.L. (1997). Shoot axillary bud morphogenesis in kiwifruit (Actinidia deliciosa). Ann. Bot. 80,13-21. https://doi.org/10.1006/anbo.1996.0381.

Walton, E.F., Podivinsky, E., and Wu, R.M. (2001). Bimodal patterns of floral gene expression over the two seasons that kiwifruit flowers develop. Physiol. Plant. 111, 396-404. https://doi.org/10.1034/ j.1399-3054.2001.1110318.x.

Walton, E.F., Wu, R.M., Richardson, A.C., Davy, M., Hellens, R.P., Thodey, K., Janssen, B.J., Gleave, A.P., Rae, G.M., Wood, M., and Schaffer, R.J. (2009). A rapid transcriptional activation is induced by the dormancy-breaking chemical hydrogen cyanamide in kiwifruit (Actinidia deliciosa) buds. J. Exp. Bot. 60, 3835-3848. https://doi. org/10.1093/jxb/erp231.

Wang, Y., Georgi, L., Reighard, G., Scorza, R., and Abbott, A. (2002). Genetic mapping of the evergrowing gene in peach [Prunus persica (L.) Batsch]. J. Hered. 93, 352-358. https://doi.org/10.1093/ jhered/93.5.352.

Wu, R.M., Walton, E.F., Richardson, A.C., Wood, M., Hellens, R.P., and Varkonyi-Gasic, E. (2012). Conservation and divergence of four kiwifruit SVP-like MADS-box genes suggest distinct roles in kiwifruit bud dormancy and flowering. J. Exp. Bot. 63, 797-807. https://doi. org/10.1093/jxb/err304. 
Wu, R., Wang, T., McGie, T., Voogd, C., Allan, A.C., Hellens, R.P., and Varkonyi-Gasic, E. (2014). Overexpression of the kiwifruit SVP3 gene affects reproductive development and suppresses anthocyanin biosynthesis in petals, but has no effect on vegetative growth, dormancy, or flowering time. J. Exp. Bot. 65, 4985-4995. https://doi. org/10.1093/jxb/eru264.

Wu, R., Tomes, S., Karunairetnam, S., Tustin, S.D., Hellens, R.P., Allan, A.C., Macknight, R.C., and Varkonyi-Gasic, E. (2017a). SVP-like MADS box genes control dormancy and budbreak in apple. Front. Plant Sci. 8, 477. https://doi.org/10.3389/fpls.2017.00477.

Wu, R., Wang, T., Warren, B., Allan, A.C., Macknight, R.C., and Varkonyi-Gasic, E. (2017b). Kiwifruit SVP2 gene prevents premature budbreak during dormancy. J. Exp. Bot. 68, 1071-1082. https://doi. org/10.1093/jxb/erx014.

Wu, R., Wang, T., Warren, B., Thomson, S.J., Allan, A.C., Macknight, R.C., and Varkonyi-Gasic, E. (2017c). Kiwifruit SVP2 controls developmental and drought-stress pathways. Plant Mol. Biol. 96, 233-244. https://doi.org/10.1007/s11103-017-0688-3.

Yamane, H., Kashiwa, Y., Ooka, T., Tao, R., and Yonemori, K. (2008). Suppression subtractive hybridization and differential screening reveals endodormancy-associated expression of an SVP/AGL24-type MADS-box gene in lateral vegetative buds of Japanese apricot. J. Am. Soc. Hortic. Sci. 133, 708-716.

Yamane, H., Ooka, T., Jotatsu, H., Hosaka, Y., Sasaki, R., and Tao, R. (2011). Expressional regulation of PpDAM5 and PpDAM6, peach (Prunus persica) dormancy-associated MADS-box genes, by low temperature and dormancy-breaking reagent treatment. J. Exp. Bot. 62, 3481-3488. https://doi.org/10.1093/jxb/err028.

Yu, H., Xu, Y., Tan, E.L., and Kumar, P.P. (2002) AGAMOUS-LIKE 24, a dosage-dependent mediator of the flowering signals. Proc. Natl. Acad. Sci. USA 99, 16336-16341. https://doi.org/10.1073/ pnas.212624599.

Yu, H., Ito, T., Wellmer, F., and Meyerowitz, E.M. (2004). Repression of AGAMOUS-LIKE 24 is a crucial step in promoting flower development. Nat. Genet. 36, 157-161. https://doi.org/10.1038/ ng1286.

Received: May 5, 2017

Accepted: Feb. 20, 2018

Address of author:

Rongmei Wu

The New Zealand Institute for Plant \& Food Research Ltd.,

Mt. Albert, Private Bag 92169, Auckland Mail Centre,

Auckland 1142, New Zealand

E-mail: rongmei.wu@plantandfood.co.nz;

Tel.: +6499257270 